\title{
Transgenic Resistance to Cucumber Mosaic Virus in Tomato: Blocking of Long-Distance Movement of the Virus in Lines Harboring a Defective Viral Replicase Gene
}

\author{
Amit Gal-On, Dalia Wolf, Yongzeng Wang, Jean-Emmanuelle Faure, Meir Pilowsky, and Aaron Zelcer
}

First and third authors: Department of Plant Virology; and second, fourth, fifth, and sixth authors: Department of Plant Genetics, ARO, The Volcani Center, P.O. Box 6, Bet Dagan 50250, Israel.

Accepted for publication 10 July 1998.

\begin{abstract}
Gal-On, A., Wolf, D., Wang, Y., Faure, J.-E., Pilowsky, M., and Zelcer, A. 1998. Transgenic resistance to cucumber mosaic virus in tomato: Blocking of long-distance movement of the virus in lines harboring a defective viral replicase gene. Phytopathology 88:1101-1107.

Tomato breeding lines were transformed with a defective replicase gene from RNA 2 of cucumber mosaic virus (CMV). A total of 63 transformants from five tomato genotypes were evaluated for resistance to CMV strains. The responses of R1 transgenic offspring fit into three categories: fully susceptible lines (44\%), fully resistant lines (8\%), and an intermediate-type mixture of susceptible and resistant seedlings in variable proportions $(48 \%)$. Further characterization of the response of two highly resistant lines was performed by mechanical inoculation, aphid

initially in the inoculated leaf. The homozygous R2 plants and further generations that were evaluated (up to R5) showed resistance to the FnyCMV strain, two Israeli isolates tentatively classified as subgroup IA, and K-CMV (a representative of subgroup IB). These lines were partially resistant to LS-CMV (a representative of subgroup II) when a high-virustiter inoculum was used. Expression of the viral transgene was verified in these lines; however, the expected translation product was not detectable. In grafting experiments, we demonstrated that CMV virions were blocked in their ability to move from infected rootstocks of nontransformed tomato or tobacco into the transgenic scions. Interestingly, virions could not move through a transgenic intersection into the upper scion. These results provide an additional indication that replicase-mediated resistance affects long-distance movement.
\end{abstract} transmission, or grafting experiments. No virus was detected in noninoculated leaves from these lines, although a low level of virus accumulated
Additional keywords: virus resistance, viral movement, graft inoculation.
Cucumber mosaic virus (CMV) is a member of the genus $\mathrm{Cu}$ cumovirus. Cucumoviruses have a split RNA genome and two subgenomic RNAs; RNA 4 is derived from RNA 3 and, in CMV subgroup II, RNA 4A is derived from RNA 2 (10). These RNAs are encapsidated in isometric particles containing RNA 1, RNA 2, and RNA 3 plus 4 (27). The $1 \mathrm{a}$ and $2 \mathrm{a}$ proteins encoded by RNA 1 and RNA 2, respectively, are a part of the viral replicase complex (19). The movement of cucumoviruses from cell to cell and through the plant (long distance) requires the 3 a movement protein (MP) $(21,36)$ and the coat protein (CP) (37). The association of the 1a protein with viral movement, as well as replication, has been demonstrated in squash and tobacco $(15,33)$ and in transgenic plants $(6)$.

CMV causes severe worldwide epidemics in tomato crops (38). Many attempts to incorporate a source of resistance to CMV into tomato have failed $(22,29,43)$. The ability to confer resistance against plant viruses by introducing pathogen-derived sequences into the genome of a potential host has been documented in many studies $(4,24)$. Attempts to produce tomato resistant to CMV by transformation with CP $(17,30,41)$ or satellite RNA genes (34) have resulted in various degrees of protection against CMV infection. Resistance induced by replicase genes of RNA viruses (termed replicase-mediated resistance) also has been reported in many instances in recent years, following the pioneer work with tobacco mosaic virus (TMV) $(5,28)$.

Anderson et al. (1) transformed tobacco lines with a truncated cDNA clone of Fny-CMV RNA 2. A 94-bp deletion in the "poly-

Corresponding author: A. Gal-On; E-mail address: vpamit@volcani.agri.gov.il

Publication no. P-1998-0811-01R

(C) 1998 The American Phytopathological Society merase active site" (GDD) resulted in a frameshift and generated a truncated reading frame encoding a $75-\mathrm{kDa}$ protein compared with a 96-kDa wild-type protein. Biochemical analysis of the resistant tobacco lines revealed that neither viral RNA nor the virus itself could be detected in upper leaves of some resistant plants. The resistance was effective against strains of subgroup 1A of CMV following either mechanical inoculation with viral RNA or aphid transmission (42). Additionally, resistance to some subgroup 1B strains, but not to subgroup II strains $(20,42)$, has been reported. The resistance mechanism seems very complex (20); in addition to inhibition of replication, there are restrictions on cell-to-cell (26) and long-distance movement (6). Recently, Wintermantel et al. (40) demonstrated by in situ hybridization that CMV was unable to enter the conducting elements of the vascular system in transgenic tobacco exhibiting replicase-mediated resistance. When such transgenic tobacco was grafted onto a nontransformed tobacco rootstock, which was subsequently inoculated, the virions could move into the transgenic scion, although a marked delay in virus accumulation was observed. Whether this effect was due to a putative truncated 2a protein (6) or to a RNA-mediated resistance mechanism (20) is still an unresolved issue. The involvement of replicase in virus movement has been shown previously for brome mosaic virus (39) and CMV $(6,15)$.

In the current study, by using the construct of Anderson et al. (1), we demonstrate an even higher resistance to CMV in tomato breeding lines than was demonstrated in tobacco $(6,20,42)$. Longdistance movement of CMV was blocked in resistant plants, supporting the observations reported by Arce-Johnson et al. (3). Our results reinforce current thinking on the requirement of either viral replication or the presence of functional replicase proteins for systemic spread of virus within infected plants (3). 


\section{MATERIALS AND METHODS}

Tomato transformation. The plasmid pCMV N/B-23, harboring a defective CMV replicase gene and known to elicit resistance in tobacco (1) was provided by M. Zaitlin and P. Palukaitis (Department of Plant Pathology, Cornell University). Leaf and cotyledon explants from five advanced tomato breeding lines or from inbred lines used as parents in the local production of F1 hybrids (these proprietary tomato lines were given a numerical code, for the sake of simplicity) were transformed with Agrobacterium tumefaciens LB 4404 harboring the above-mentioned binary vector, as described by McCormick (25).

Most of the regenerated R0 plants were transferred to a contained greenhouse. Selfed progeny (R1 seeds) from fertile plants were germinated on aseptic selective medium in order to verify the expression of kanamycin resistance and to screen for homozygous lines. Susceptibility to kanamycin $(100 \mu \mathrm{g} / \mathrm{ml})$ was manifested in young seedlings as a severe inhibition of elongation of the primary root and lack of root branching.

Virus strains and inoculation. Five strains of CMV were used. Fny-CMV, LS-CMV, and K-CMV were provided by P. Palukaitis from Cornell's plant virus collection. We also used two local isolates putatively classified as subgroup IA strains, Is-CMV and a satellite RNA-containing strain obtained from banana plants (14). Virus was purified from infected tobacco (Nicotiana tabacum cv. Xanthi NN) as previously described by Palukaitis et al. (27). Tomato seeds (Lycopersicon esculentum) were germinated in individual pots, and about 7 to 10 days after germination, the cotyledons were dusted with Carborundum and mechanically inoculated. Two $5-\mu l$ aliquots of purified virus at $1 \mathrm{mg} / \mathrm{ml}$ of buffer C $(5 \mathrm{mM}$ sodium borate and $0.5 \mathrm{mM}$ EDTA, $\mathrm{pH}$ 9) were used per seedling in all experiments.

Evaluation of the resistance response. Kanamycin-resistant R1 seedlings from putative transgenic progenies were screened under greenhouse conditions for viral resistance by mechanical inoculation with purified Fny-CMV. For most progenies, more than 10 seedlings were initially screened by inoculation. To assess resistance, inoculated seedlings were kept for several weeks under greenhouse conditions with a day length of $16 \mathrm{~h}$ and a constant temperature of $22^{\circ} \mathrm{C}$. The percentages of infection, resistance, or both of nontransformed and transformed plants were determined by visual inspection and by enzyme-linked immunosorbent assay (ELISA) in all experiments.

ELISA assays. Inoculated tomato lines were analyzed for the presence of various strains of CMV by antigen-coated plate (ACP)ELISA (23) using a specific antiserum $(1: 4,000)$ prepared against LS-CMV or Fny-CMV.

Aphid transmission. Transmission of virus by Aphis gossypii was performed as described by Antignus et al. (2). Fny-CMV-infected zucchini (Cucurbita pepo cv. Maayan) were used as sources of virus for a 5- to 10-min acquisition access period. Approximately 10 aphids per tomato seedling were used for inoculation.

DNA extraction and analysis. Genomic DNA was extracted from $5 \mathrm{~g}$ of young leaves (about 3 weeks after germination) from each individual R1 line, according to Doyle and Doyle (12). About $10 \mu \mathrm{g}$ of EcoRI-digested DNA was analyzed by gel blot hybridiza-

TABLE 1. Number of putative transgenic R0 clones obtained by transformation of different tomato genotypes with a truncated replicase gene of cucumber mosaic virus

\begin{tabular}{lcc}
\hline Genotype & Total independent regeneration area & Total transformants \\
\hline 6 & 36 & 61 \\
2 & 13 & 23 \\
7 & 12 & 22 \\
4 & 9 & 15 \\
5 & 7 & 15 \\
Others & 3 & 3 \\
Total & 80 & 139 \\
\hline
\end{tabular}

TABLE 2. Polymerase chain reaction (PCR) analysis and level of resistance to cucumber mosaic virus (CMV) in transgenic tomato lines

\begin{tabular}{|c|c|c|c|}
\hline Transgenic lines ${ }^{\mathrm{w}}$ & $\mathrm{PCR}^{\mathrm{x}}$ reaction & Susceptible/totaly & $\%$ Susceptible \\
\hline \multicolumn{4}{|l|}{ Genotype 6} \\
\hline 6.1 & + & $1 / 26$ & 3.8 \\
\hline 6.2 & + & $3 / 27$ & 11.1 \\
\hline $6.3 \mathrm{a}$ & + & $9 / 16$ & 56.3 \\
\hline $6.3 \mathrm{~b}$ & + & $13 / 13$ & 100.0 \\
\hline $6.4 \mathrm{a}$ & + & $27 / 30$ & 90.0 \\
\hline $6.4 \mathrm{~b}$ & + & $12 / 16$ & 75.0 \\
\hline $6.5 \mathrm{a}$ & + & $12 / 14$ & 85.7 \\
\hline $6.5 b$ & + & $6 / 18$ & 33.3 \\
\hline 6.6 & + & $25 / 26$ & 96.1 \\
\hline 6.7 & + & $15 / 15$ & 100.0 \\
\hline 6.8 & + & $18 / 42$ & 42.8 \\
\hline 6.9 & + & $12 / 12$ & 100.0 \\
\hline 6.10 & + & $15 / 15$ & 100.0 \\
\hline 6.11 & + & $10 / 10$ & 100.0 \\
\hline 6.12 & + & $10 / 28$ & 35.7 \\
\hline 6.13 & + & $7 / 8$ & 87.5 \\
\hline 6.15 & + & $7 / 7$ & 100.0 \\
\hline 6.16 & + & $8 / 8$ & 100.0 \\
\hline 6.17 & + & $24 / 33$ & 72.7 \\
\hline Nontransformed & - & $41 / 42$ & 97.6 \\
\hline \multicolumn{4}{|l|}{ Genotype 7} \\
\hline $7.1 \mathrm{a}$ & nd & $23 / 25$ & 92.0 \\
\hline $7.1 \mathrm{~b}$ & + & $14 / 14$ & 100.0 \\
\hline $7.2 * \mathrm{Z}$ & + & $0 / 31$ & 0 \\
\hline 7.3 & + & $13 / 24$ & 54.1 \\
\hline $7.4 a^{*}$ & + & $0 / 26$ & 0 \\
\hline $7.4 \mathrm{~b}$ & + & $3 / 12$ & 25.0 \\
\hline $7.4 c^{*}$ & + & $0 / 15$ & 0 \\
\hline $7.5 \mathrm{a}$ & + & $7 / 14$ & 50.0 \\
\hline $7.5 b$ & + & $4 / 15$ & 26.6 \\
\hline $7.5 \mathrm{c}$ & + & $14 / 30$ & 46.6 \\
\hline $7.6 \mathrm{a}$ & + & $18 / 36$ & 50.0 \\
\hline $7.6 \mathrm{~b}$ & nd & $9 / 15$ & 60.0 \\
\hline 7.7 & + & $20 / 40$ & 50.0 \\
\hline 7.8 & + & $14 / 14$ & 100.0 \\
\hline Nontransformed & - & $60 / 62$ & 96.7 \\
\hline \multicolumn{4}{|l|}{ Genotype 4} \\
\hline $4.1^{*}$ & + & $0 / 29$ & 0 \\
\hline $4.2 \mathrm{a}$ & - & $43 / 46$ & 93.4 \\
\hline $4.2 b$ & - & $14 / 15$ & 93.3 \\
\hline Nontransformed & - & $46 / 46$ & 100.0 \\
\hline \multicolumn{4}{|l|}{ Genotype 5} \\
\hline 5.1 & nd & $8 / 16$ & 50.0 \\
\hline 5.2 & + & $4 / 16$ & 25.0 \\
\hline 5.3 & + & $8 / 25$ & 32.0 \\
\hline $5.4 \mathrm{a}$ & + & $10 / 15$ & 66.6 \\
\hline $5.4 \mathrm{~b}$ & + & $8 / 16$ & 50.0 \\
\hline $5.5 \mathrm{a}$ & nd & $10 / 10$ & 100.0 \\
\hline $5.5 \mathrm{~b}$ & + & $10 / 10$ & 100.0 \\
\hline $5.5 \mathrm{c}$ & + & $14 / 15$ & 93.3 \\
\hline $5.6 \mathrm{a}$ & + & $9 / 9$ & 100.0 \\
\hline $5.6 \mathrm{~b}$ & + & $7 / 11$ & 63.6 \\
\hline Nontransformed & - & $34 / 36$ & 94.4 \\
\hline \multicolumn{4}{|l|}{ Genotype 2} \\
\hline 2.1 & + & $11 / 20$ & 55.0 \\
\hline $2.2 a^{*}$ & + & $0 / 10$ & 0 \\
\hline $2.2 b$ & + & $5 / 28$ & 17.8 \\
\hline $2.2 \mathrm{c}$ & + & $5 / 15$ & 33.3 \\
\hline $2.2 \mathrm{~d}$ & + & $5 / 14$ & 35.7 \\
\hline $2.3 \mathrm{a}$ & + & $15 / 36$ & 41.6 \\
\hline $2.3 b$ & + & $21 / 30$ & 70.0 \\
\hline $2.3 \mathrm{c}$ & + & $8 / 8$ & 100.0 \\
\hline $2.4 \mathrm{a}$ & - & $7 / 7$ & 100.0 \\
\hline $2.4 \mathrm{~b}$ & - & $7 / 7$ & 100.0 \\
\hline $2.4 \mathrm{c}$ & nd & $15 / 15$ & 100.0 \\
\hline $2.4 \mathrm{~d}$ & - & $15 / 15$ & 100.0 \\
\hline 2.5 & + & $8 / 8$ & 100.0 \\
\hline 2.6 & + & $15 / 15$ & 100.0 \\
\hline 2.7 & + & $11 / 15$ & 73.3 \\
\hline Nontransformed & - & $60 / 63$ & 95.2 \\
\hline \multicolumn{4}{|l|}{ Genotype 1} \\
\hline 1.1 & & $14 / 15$ & 93.3 \\
\hline 1.2 & & $15 / 15$ & 100.0 \\
\hline
\end{tabular}

${ }^{\mathrm{w}}$ Each numbered line represents the progeny of individual regenerants. Lines with an identical number but marked $\mathrm{a}, \mathrm{b}$, or $\mathrm{c}$ were putatively isolated from the same site on the explant.

${ }^{\mathrm{x}}$ The presence of the replicase gene in R1 plants was verified by PCR $(+=$ sequence detected, $-=$ sequence not detected, and nd $=$ not determined).

y R0 plants were selfed, and R1 seeds were germinated in the presence of kanamycin. Kanamycin-resistant seedlings were evaluated for resistance to CMV. The number of susceptible seedlings out of the total inoculated is shown.

${ }^{\mathrm{z}}$ Fully resistant lines are indicated by $*$. 
tion on Hybond $\mathrm{N}$ membrane (Amersham International plc., Little Chalfont, United Kingdom). Blotted DNA was hybridized with a ${ }^{32} \mathrm{P}$-labeled polymerase chain reaction (PCR) cDNA fragment corresponding to the sequence from nucleotide 1,112 to nucleotide 1,727 of CMV RNA 2 (32) and previously labeled with a random prime labeling kit (Boehringer GmbH, Mannheim, Germany).

PCR analysis. Total genomic DNA from each R1 transgenic line was extracted by the Dellaporta et al. (8) procedure. One microliter of the DNA was diluted in $20 \mu \mathrm{l}$ of PCR reaction mixture containing primers generated according to the published sequence of CMV RNA 2 (32) (5'-GAGCGGTCACAAGAGAGTAG-3' and 5'-GGAAATCACACCACCACTTA-3', located at positions 1,113 and 1,747, respectively). PCR conditions were 35 cycles of 1 min at $94^{\circ} \mathrm{C}, 1 \mathrm{~min}$ at $55^{\circ} \mathrm{C}$, and $1 \mathrm{~min}$ at $72^{\circ} \mathrm{C}$.

Extraction and analysis of RNA. Expression of the viral transgene was tested by Northern blot analysis of total RNA extracted from seedlings 3 weeks after germination. Three hundred milligrams of tissue from young leaves was ground to a fine powder in liquid nitrogen. The powder was further ground with RNA extraction buffer ( $8 \mathrm{M}$ guanidium- $\mathrm{HCl}, 20 \mathrm{mM}$ morpholineethanesulfonic acid, $20 \mathrm{mM}$ EDTA, and $50 \mathrm{mM} \beta$-mercaptoethanol) and phenol ( $\mathrm{pH} \mathrm{4.5)/chloroform.} \mathrm{After} \mathrm{incubation} \mathrm{for} 20 \mathrm{~min}$, the mixture was centrifuged at $10,000 \times g$ for $30 \mathrm{~min}$ and the upper phase was collected. Total RNA was precipitated from the upper phase with the addition of one volume of isopropanol and centrifuged at $10,000 \times g$ for $20 \mathrm{~min}$. RNA concentrations were determined by spectrophotometry and comparable amounts of RNAs were loaded onto gels. Plus-sense CMV-specific RNAs were then detected by Northern blot hybridization (21). About $10 \mu \mathrm{g}$ of each sample was electrophoresed in a denaturing $1.5 \%$ agarose gel containing formaldehyde, transferred to a nitrocellulose membrane (Schleicher \& Schuell, Inc., Dassel, Germany), and hybridized with the same probe as used for the DNA analysis.

Extraction and analysis of CMV RNAs accumulated in the inoculated leaf. Four plants of transformed or nontransformed genotypes were inoculated (five leaves on each plant) with purified Fny-CMV. The inoculated leaves were rinsed with tap water $10 \mathrm{~min}$ after inoculation. Four leaf discs, $10 \mathrm{~mm}$ in diameter (about $100 \mathrm{mg}$ total weight), were collected at each time point. Total RNA of infected tissues was extracted as described previously by Kaplan et al. (21). Comparable amounts of total RNA $(5 \mu \mathrm{g})$ were loaded and separated on denaturing $1.5 \%$ agarose gels and blotted onto nitrocellulose membranes. CMV RNAs were detected by hybridization with ${ }^{32} \mathrm{P}$-labeled RNA transcripts complementary to the $3^{\prime}$ noncoding region common to each RNA (15). A Kodak 40 digital camera (Kodak, Rochester, NY) was used to photograph the exposed X-ray films. The BioMax 1D application (Kodak) was used for quantitative analysis of the image.

Grafting plants. Two different grafting techniques were tested: leaf grafting, a leaf with axillary bud from an infected source tomato plant was side-grafted onto the challenged plant, which bore three or four leaves (about 3 weeks after germination); and top grafting, a challenged scion was grafted by making a V-shaped notch on top of an infected nontransformed tomato or tobacco rootstock 3 weeks after inoculation (40). When required, intergrafts were then generated by pruning some of the top scions to a $5-\mathrm{cm}$ length 4 weeks after the first top-grafting and by subsequently topgrafting an upper scion of a susceptible tomato.

\section{RESULTS}

Transformation of different tomato genotypes. Most of the transformation work was performed on five different genotypes (Table 1). Three parental lines from commercial F1 hybrids (genotypes 2, 7, and 4) and two advanced breeding lines (genotypes 5 and 6) are represented. Discrete transformation sites on the explants, yielding shoots under selection conditions, were regarded as independent transformation events. A total of 139 putative transform- ants, representing at least 80 independent transformation events, were obtained for all the genotypes included in this study (Table 1). For practical reasons and to maximize the overall variability among the transformed population, no more than one to three transformants were isolated from each transformed (regenerated) area. Differences in transformation efficiency were observed among genotypes (data not shown); however, Table 1 only includes the absolute number of transformants obtained for the various genotypes.

The segregation data for resistance or susceptibility to kanamycin for each individual progeny indicated that most (92\%) of the original R0 transformants carried one functional insert, while few $(8 \%)$ of the R0 transformants appeared to carry several unlinked inserts (data not shown).

Evaluation of resistance in transgenic lines. The responses of kanamycin-resistant R1 seedlings to CMV infection fit into three categories: (i) highly susceptible progenies exhibiting greater than $87 \%$ infection (28 lines); (ii) fully resistant progenies in which no infected seedlings were detected (five lines from three different genotypes); and (iii) intermediate responses (30 lines), i.e., lines with a mixture of infected and noninfected seedlings in variable proportions (Table 2). The infection of seedlings in the three categories (as initially determined by visual symptoms) was subsequently confirmed by ELISA. Extracts from individual seedlings from fully resistant lines (category 2) were back-inoculated to tobacco and squash. In all instances in which seedlings scored negative according to visible symptoms, seedlings were confirmed as noninfected by ELISA and back-inoculation. R1 progenies were tested concomitantly for the presence of the truncated replicase transgene by PCR. This sequence was detected in 51 lines, but not in five susceptible lines (Table 2). Two of the fully resistant lines, lines 4.1 and 7.2 (hereafter referred to as lines 4 and 7 , respectively) (Table 2) were selected for further virological and biochemical characterization.

The response to inoculation with different CMV strains was tested by mechanical inoculation (Table 3, Fig. 1). These lines were fully resistant to representative strains from subgroup IA, Fny-CMV, and a local Israeli strain. Interestingly, these lines were also fully resistant to K-CMV, a member of subgroup IB (Fig. 1, Table 3). However, only partial resistance in line 4 and no resistance in line 7 were observed to the LS-CMV strain, a representative of subgroup II (Table 3). A local strain very closely related to Fny-CMV, and harboring a satellite RNA (13) also evoked a fully resistant response (data not shown).

Since CMV is naturally transmitted by aphids under field conditions, the resistant lines were subjected to aphid-mediated in-

TABLE 3. Evaluation of resistance to cucumber mosaic virus in two transgenic tomato lines by three different methods of virus inoculation

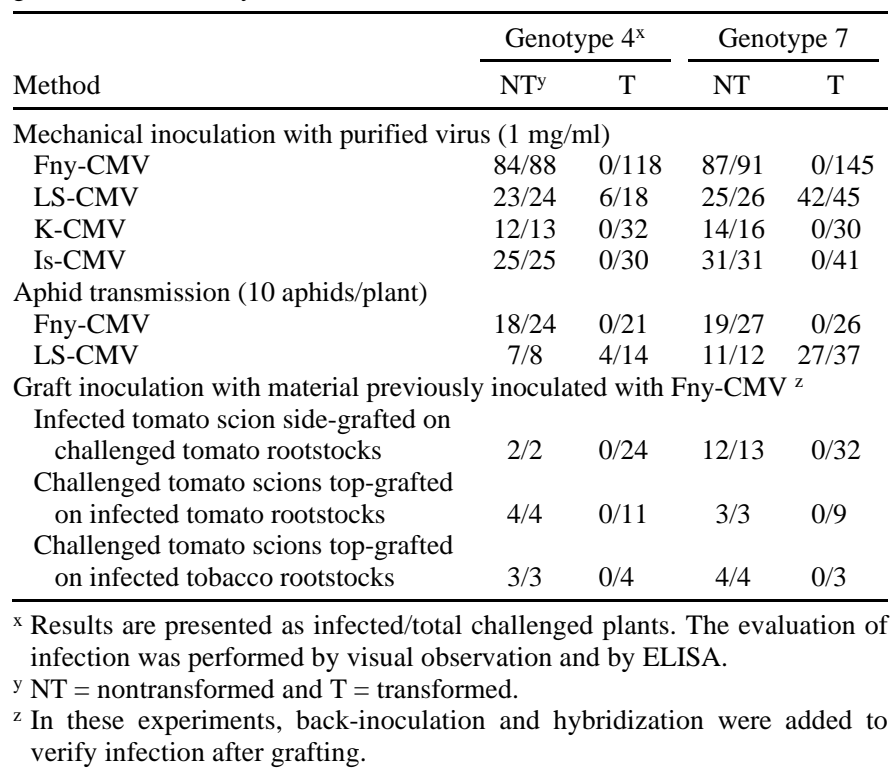


oculation. The nontransformed control seedlings showed a 70 to $75 \%$ efficiency of transmission. The transgenic lines were fully resistant to Fny-CMV, but only partially resistant to LSCMV, similar to what was observed for mechanical inoculation (Table 3).

The resistant lines were inoculated by grafting in order to evaluate their response under a regime of continuous CMV challenge from adjacent infected tissues (Table 3). No symptoms were observed and no virus was detected by ELISA or back-inoculation in stems or leaves from resistant lines 10 weeks after being challenged by leaf-grafting or top-grafting (Table 3). Virtually all nontransformed plants showed the onset of severe symptoms 10 to 14 days after grafting (Table 3). Moreover, since tobacco is known to accumulate a very high titer of CMV, resistant genotypes were topgrafted onto infected tobacco rootstocks. Nontransformed scions showed marked symptoms after 7 to 10 days. Susceptibility in

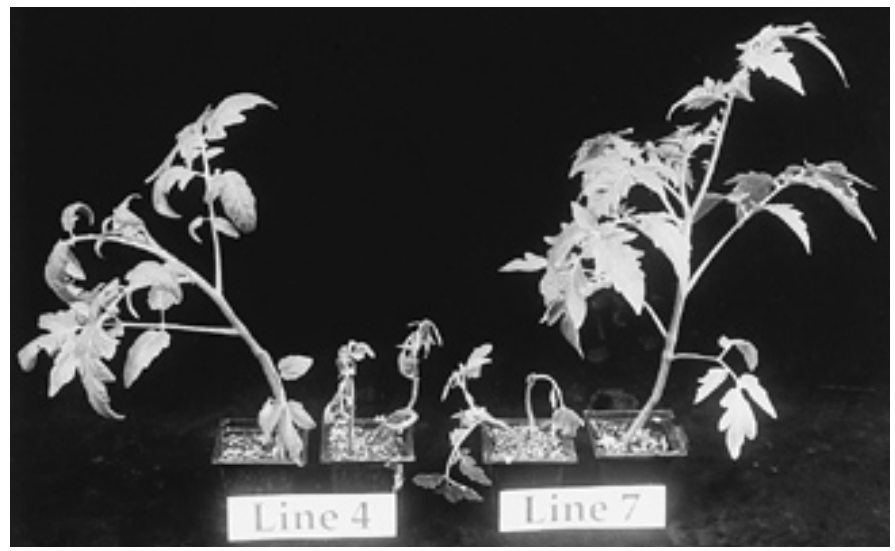

Fig. 1. Response of nontransformed and transgenic tomato plants from genotypes 4 and 7 to mechanical inoculation with the cucumber mosaic virus (CMV) strain K-CMV. For each genotype, one transgenic (outside) and two nontransformed (inside) plants were inoculated 1 week after germination and documented 3 weeks later. transgenic scions was monitored for 3 months; no symptoms developed (Table 3 ) and no virus was detected by ELISA, back-inoculation, or Northern blotting (data not shown). Normal fruit set and fruit development were observed in challenged scions under these conditions (data not shown).

Characterization of the transgenic lines. In parallel with the evaluation of the resistance response in the two highly resistant lines, a molecular characterization of the transgene and its expression was performed in R2 homozygous plants from these lines. The expected truncated version of the replicase transcript was detected in both resistant lines 4 and 7, as well as in a susceptible line from genotype 5 (Fig. 2A). No obvious correlation was evident between the level of expression and the resistance response. A marked difference in the level of expression in the resistant lines was observed. Moreover, slightly higher expression was observed in the susceptible line 5 than in one of the resistant lines, line 7 . The higher expression in line 4 could be due to a higher transgene copy level than in line 7 , and further data is necessary to evaluate this point (Fig. 2B). No data on the chromosomal location or on the possible linkage of the different inserts is currently available. In both resistant lines ( 4 or 7 ), the expression of the putative translation product of the defective 2 a gene could not be detected by Western blotting under conditions that allowed for visualization of this protein in transgenic tobacco plants (6) (data not shown).

Accumulation of CMV RNAs in inoculated leaves from the transgenic lines. To study the mechanism of the resistance response, the accumulation of CMV RNAs in the inoculated leaves was monitored at various times after mechanical inoculation of R2 homozygous plants (Fig. 3A). No visible symptoms were observed in inoculated leaves of transgenic or nontransformed plants. To compare the level of accumulation of viral RNAs in inoculated leaves of transgenic lines with the level observed in nontransformed lines, a parallel probing was performed 7 days postinoculation. About threefold to 10 -fold lower accumulation was detected in the transgenic lines 4 and 7, respectively, than in their nontransformed counterparts (Fig. 3B). Even though similar levels of viral RNA were detected in both re-

A

B
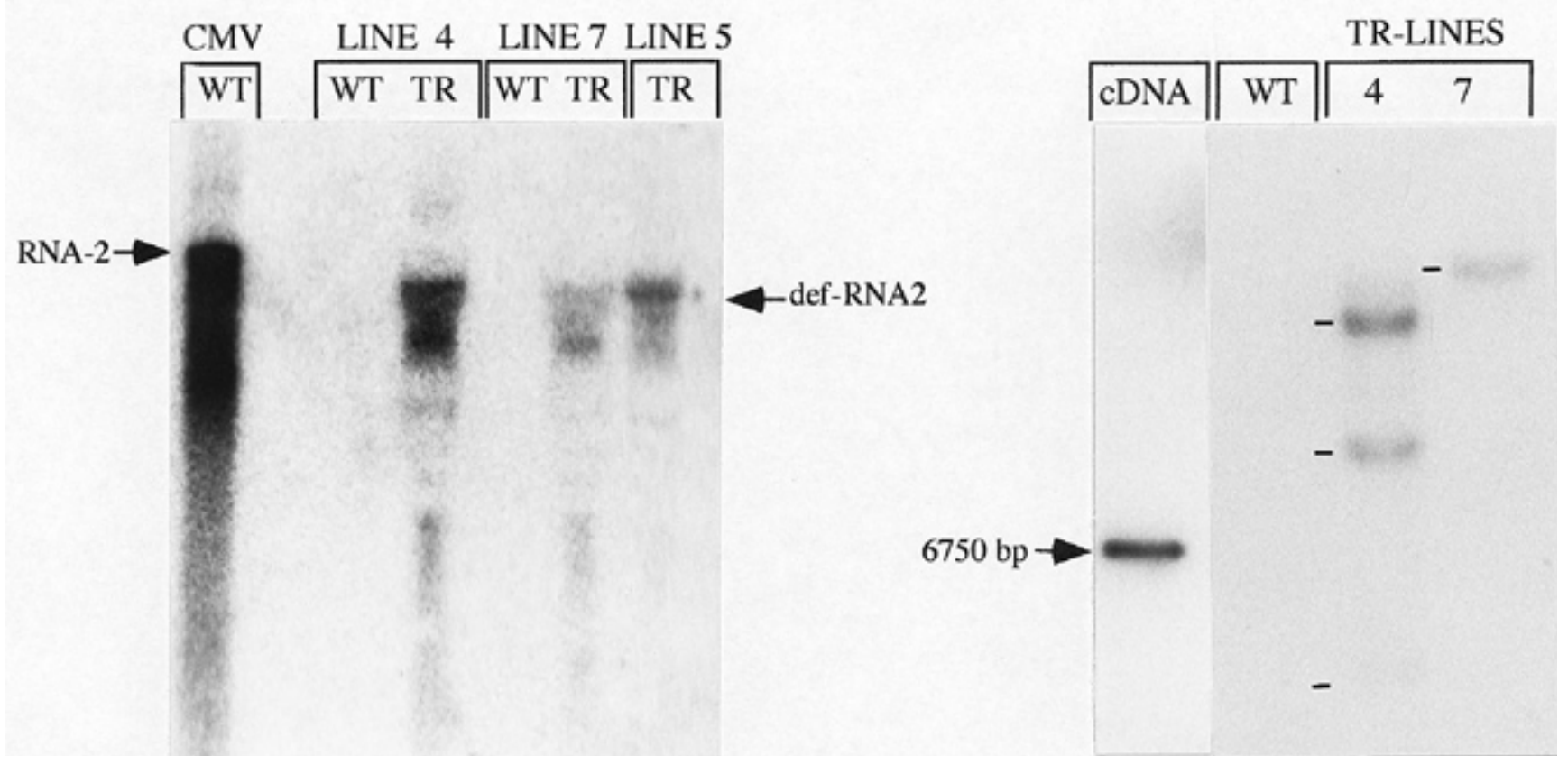

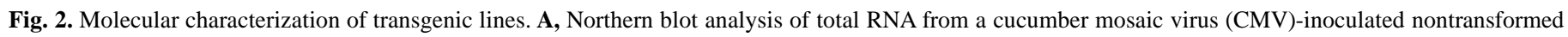

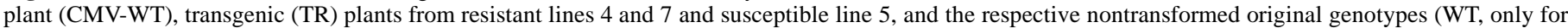

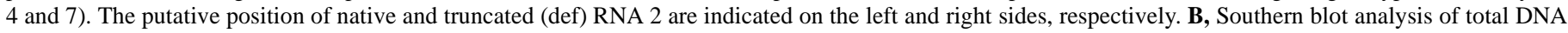

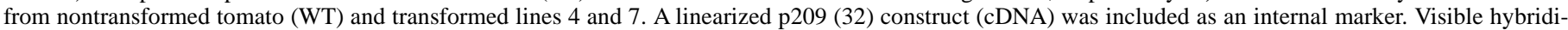
zation bands are marked. Northern and Southern blots were probed with a 635-bp polymerase chain reaction fragment from the internal region of CMV RNA 2. 
sistant lines at 8 days postinoculation, the onset of accumulation in line 4 occurred earlier than in line 7 (Fig. 3A).

Systemic movement of CMV through a stem intergraft. Our data appear to indicate that a certain degree of viral replication or cell-to-cell movement occurs in inoculated leaves of resistant plants. Nevertheless, the top-grafting experiments showed that no virus was found in the transgenic scions. We, therefore, evaluated in a more direct way whether the long-distance movement of CMV might be affected in our transgenic plants. An intergraft section of either transgenic or nontransformed origin was established in order to assess the long-distance movement of CMV from an infected rootstock, through the intergraft section, and into a susceptible upper scion. A nontransformed or transgenic shoot was grafted on top of a CMV-infected tomato rootstock. After 4 weeks, these scions were pruned and nontransformed shoots were then grafted on top of these intergraft sections. The upper scions were evaluated for the establishment of infection. In each instance in which a nontransformed intergraft was used, symptoms were observed in the upper scion 10 days after the second grafting. For genotype 4, six out of six scions developed symptoms; for genotype 7, three out of three scions developed symptoms. However, all challenged scions that were grafted on top of transgenic intergrafts did not develop any symptoms (zero out of three and nine scions for genotypes 4 and 7, respectively) and scored negative for CMV by ELISA and back-inoculation.

Characterization of the resistant homozygous lines. The stability of resistance in subsequent generations of the homozygous lines was confirmed as far as the R4 generation, the last tested. Moreover, F1 hybrids that had been created by crosses between resistant line 4 plants and nontransformed lines yielded fully resistant offspring, indicating that the transgene displays a dominant trait (data not shown). The horticultural traits of either transgenic lines 4 or 7 and their hybrids seemed unaltered: under greenhouse conditions no phenotypic deviations were observed from the corresponding nontransformed pure lines or F1 hybrid in the vegetative or the fruit phases (data not shown).

\section{DISCUSSION}

The transgenic breeding of resistance to $\mathrm{CMV}$ in tomato was previously approached by genetic transformation with either viral satellite (34) or CP sequences $(17,30,41)$. We present the first results from a replicase-mediated approach, which resulted in unprecedented levels of resistance to challenge virus inoculation. In addition, limited screening with CMV strains has indicated that the resistance we detected in some highly resistant tomato lines holds against a wider range of CMV strains than that which had previously been reported for this gene in tobacco (42). The resistance of the lines generated in the current study was effective after challenge by several methods of inoculation under extreme conditions, e.g., mechanical inoculation with high virus titer or RNA concentration, aphid infestation, or continuous supply of inoculum from intra- or interspecies grafts. Using the same construct, highly resistant tobacco lines have been reported $(1,6,20)$ with similarities to the features exhibited by the tomato lines described herein. However, important differences between the responses of tobacco and tomato were observed.

The transgenic tomatoes showed resistance to the K-CMV strain, which had previously been shown to break resistance (although with a different response compared with nontransformed plants) in tobacco plants harboring the same Fny-CMV RNA 2 construct $(20,28,42)$. Discrete sequences from RNA 2 in K-CMV are responsible for this phenomenon (20). In contrast to the tobacco study, the resistant tomato line 4 does not seem as fully susceptible to LS-CMV as nontransformed plants following challenge by mechanical $(1 \mathrm{mg} / \mathrm{ml})$ or aphid-mediated inoculation (Table 3). Since the resistance response was evaluated only under extreme inoculation conditions, further work is required to fully assess the practical usefulness of this resistance when challenged by subgroup II CMV strains. The differences between transgenic tobacco and tomato in their responses to the various CMV strains could indicate that resistance is the result of a complex interplay involving a specific transgene, the identity of the challenge strain, and some host-encoded factor(s).

The inoculated tomato leaves of resistant lines invariably showed a steady accumulation of CMV RNAs at a relatively low level as compared with similarly inoculated leaves of nontransformed plants. Nevertheless, these leaves were symptomless. In contrast, tobacco lines were more variable in these aspects $(6,20)$; young inoculated leaves taken only from particular lines showed some virus accumulation and exhibited clear chlorotic lesions following inoculation

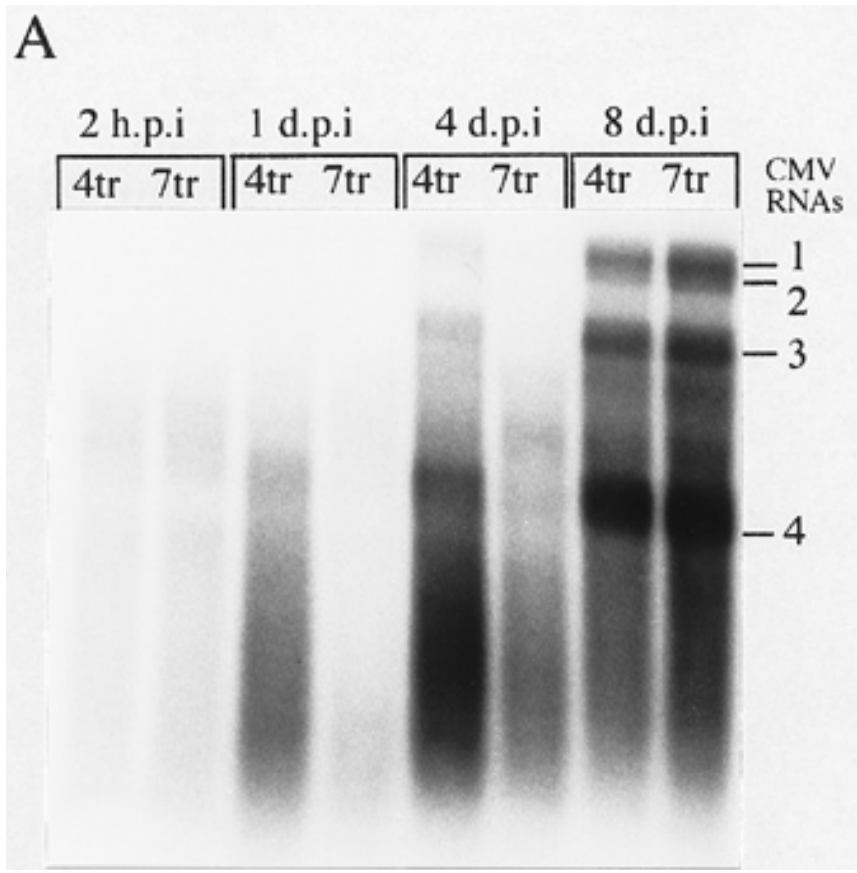

B

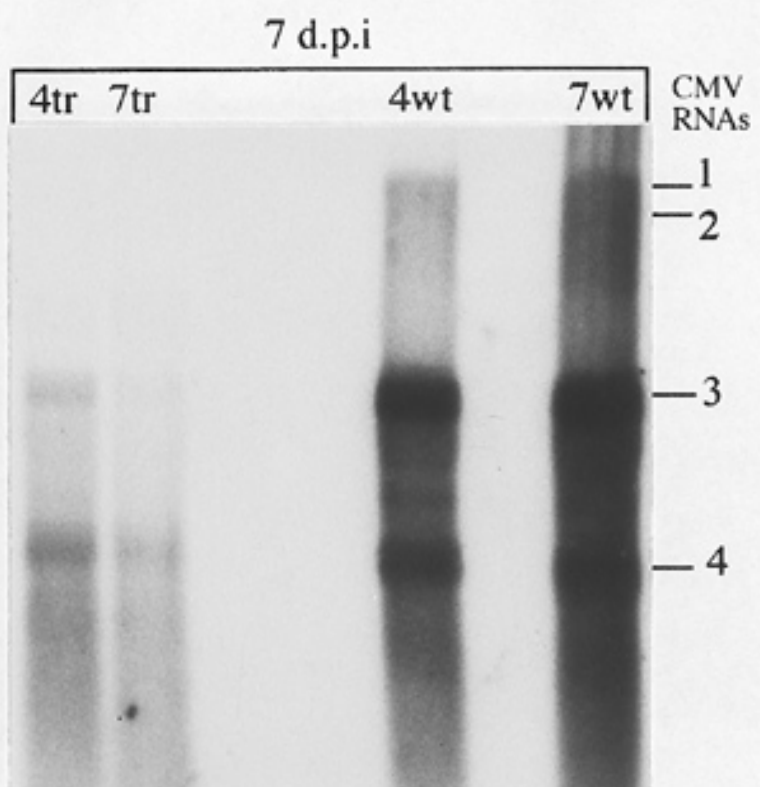

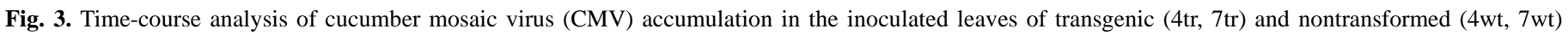

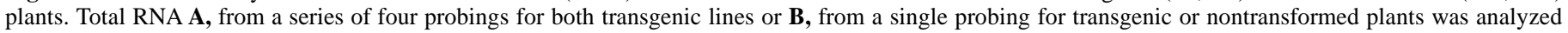
by hybridization with a transcript representing the common 3'-noncoding region of CMV. The RNA samples in A and B were taken from different plants. 
(6). It has also been reported that in inoculated tobacco leaves the truncated replicase suppresses viral accumulation by two different mechanisms: inhibition of replication as detected in protoplasts $(6,20)$ and decrease in the level of cell-to-cell movement of CMV (20). Additional studies will be needed to elucidate which of these proposed mechanisms is affecting resistance in tomato.

Inhibition of long-distance movement was also reported to be associated with replicase-mediated resistance to CMV in tobacco (6). Recently, Wintermantel et al. (40) suggested that this inhibition is the result of the inability of CMV to move from bundle sheath cells into the vascular parenchyma and companion cells, precluding entrance into the phloem. Thus, in grafting experiments, in which no barriers exist to the movement of CMV from an infected source into the phloem of resistant tobacco plants, translocation could take place and symptoms developed, although with some delay. However, our grafting experiments indicated that tomato plants harboring the same construct completely blocked long-distance movement of CMV along the vasculature. Similarly, resistance to graft-mediated inoculation has been reported for Nicotiana benthamiana harboring a $\mathrm{CP}$ transgene from potato mop-top virus (31), although in this latter work, an infected scion was grafted on top of a challenged transgenic rootstock.

Grafting may result in a temporary delay in virus movement across the developing graft union $(3,9)$. However, a successful graft will inevitably result in de novo formation of symplastic phloem connections between rootstock and scion. Since our grafted tomato plants were kept for many weeks through full fruit development in the challenged scion, we conclude that there were no physical barriers in the grafting area to stop CMV from invading the scion phloem. Additionally, we report that a transgenic intergraft completely blocked the passage of CMV virions between an infected tomato rootstock and a susceptible upper scion. This observation contrasts with previous reports of tobacco harboring the same CMV defective replicase (40), of tobacco harboring a defective TMV MP (16), and of potato harboring CP of potato leafroll virus (9).

Relatively little is known about phloem-specific barriers to longdistance movement of viruses, because of the scarcity of available information on virus phloem interactions and the lack of appropriate experimental tools. It was reported recently that MP is essential for long-distance movement of TMV in tobacco phloem, which suggests that replication is required during this process (3). Furthermore, an intergraft ("middle scion") harboring a transgenic 54-kDa gene of TMV (18) blocked the passage of this virus from the infected rootstock into the upper scion. Our results with a different virus group (cucumovirus) and a different host (tomato) resemble the above work in that a transgenic plant harboring a defective replicase specifically blocks viral movement through the phloem. As in the case of tobacco transformed with the TMV 54-kDa putative protein gene, we have not been able to detect the truncated CMV replicase product in transgenic tomato plants. Nevertheless, we cannot rule out the involvement of such a translation product in blocking virus movement in the phloem.

It is currently thought that host factors play a key role in longdistance movement of plant viruses (7). It has been reported that the mechanism of a natural resistance to CMV in pepper involves restriction of virus movement in vascular tissue (13). It has been suggested that the level of host RNA-dependent RNA polymerase ( $R d R p)$ may dictate the degree of transgenic resistance by modulating the degree of sense suppression (4). Since tomato has been reported to have a high specific activity of $\operatorname{RdRp}(35)$, it has been hypothesized that a construct expressed in this species might induce a higher level of resistance than when expressed in tobacco (28). Additionally, the current study was based on a larger number of independent transformants than had been originally reported for the tobacco studies (1). It is plausible that under the currently reported conditions, the chances for recovering individuals with higher resistance levels are increased.
RNA 1 and RNA 2 of CMV have been hypothesized to be involved in viral movement in addition to their participation in viral replication $(15,20,33)$. Recently, it was reported that the $2 b$ gene (a small open reading frame in the $3^{\prime}$ region of RNA 2) is directly involved in the long-distance movement of CMV in cucumber, but not in tobacco (11). Although no data are available to assess whether this gene product is necessary for movement of CMV in tomato, we cannot exclude the possibility that the deletion in the defective replicase construct that was used in our study could interfere with the normal expression of the $2 \mathrm{~b}$ gene, and thus affect long-distance movement.

\section{ACKNOWLEDGMENTS}

This research was supported by grant no. 261020494 from the chief scientist, Israel Ministry of Agriculture. Contribution was also from ARO, The Volcani Center, Bet Dagan, Israel, no. 502/98 series. We thank M. Zaitlin and P. Palukaitis (Department of Plant Pathology, Cornell University) for providing the recombinant binary vector $\mathrm{pCMV} \mathrm{N/B-23} \mathrm{and}$ for helpful discussions, and S. Cohen and R. Gafni (Department of Plant Virology, The Volcani Center) for support and for providing the local cucumber mosaic virus strains.

\section{LITERATURE CITED}

1. Anderson, J. M., Palukaitis, P., and Zaitlin, M. 1992. A defective replicase gene induces resistance to cucumber mosaic virus in transgenic tobacco plants. Proc. Natl. Acad. Sci. U.S.A. 89:8759-8763.

2. Antignus, Y., Raccah, B., Gal-On, A., and Cohen, S. 1989. Biological and serological characterization of zucchini yellow mosaic virus and watermelon virus-2 isolates in Israel. Phytoparasitica 17:289-298.

3. Arce-Johnson, P., Reimann-Philipp, U., Padgett, H. S., Rivera-Bustamante, R., and Beachy, R. N. 1997. Requirement of the movement protein for long distance spread of tobacco mosaic virus in grafted plants. Mol. Plant-Microbe Interact. 10:691-699.

4. Baulcombe, D. C. 1996. Mechanisms of pathogen-derived resistance to viruses in transgenic plants. Plant Cell 8:1833-1844.

5. Carr, J., and Zaitlin, M. 1993. Replicase-mediated resistance. Semin. Virol. 4:339-347.

6. Carr, J. P., Gal-On, A., Palukaitis, P., and Zaitlin, M. 1994. Replicasemediated resistance to cucumber mosaic virus in transgenic plants involves suppression of both virus replication in the inoculated leaves and long-distance movement. Virology 199:439-447.

7. Carrington, J. C., Kasschau, K. D., Mahajan, S. K., and Schaad, M. C. 1996. Cell-to-cell and long distance transport of viruses in plants. Plant Cell 8:1669-1681.

8. Dellaporta, S. L., Wood, J., and Hicks, J. B. 1983. A plant DNA minipreparation revision II. Plant Mol. Biol. Rep. 1:19-21.

9. Derrick, P. M., and Baker, H. 1997. Short and long distance spread of potato leafroll luteovirus: Effects of host genes and transgenes conferring resistance to virus accumulation in potato. J. Gen. Virol. 78:243-251.

10. Ding, S. W., Anderson, B. J., Haase, H. R., and Symons, R. H. 1994. New overlapping gene encoded by the cucumber mosaic virus genome. Virology 198:593-601.

11. Ding, S. W., Li, W. X., and Symons, R. H. 1995. A novel naturally occurring hybrid gene encoded by a plant RNA virus facilitates long distance virus movement. EMBO (Eur. Mol. Biol. Organ.) J. 14:5762-5772.

12. Doyle, J. J., and Doyle, J. L. 1990. Isolation of plant DNA from fresh tissue. Focus 12:14-16.

13. Dufour, O., Palloix, A., Gebre-Sellasie, K., Pochard, E., and Marchoux, G. 1989. The distribution of cucumber mosaic virus in resistant and susceptible plants of pepper. Can. J. Bot. 67:655-660.

14. Gafny, R., Wexler, A., Mawassi, M., Israeli, Y., and Bar-Joseph, M. 1996. Natural infection of banana by a satellite-containing strain of cucumber mosaic virus: Nucleotide sequence of the coat protein gene and satellite RNA. Phytoparasitica 24:49-56.

15. Gal-On, A., Kaplan, I., Roossinck, M. J., and Palukaitis, P. 1994. The kinetics of infection of zucchini squash by cucumber mosaic virus indicate a function for RNA 1 in virus movement. Virology 205:280-289.

16. Gera, A., Deom, C. M., Donson, J., Shaw, J. J., Lewandowski, D. J., and Dawson, W. O. 1995. Tobacco mosaic tobamovirus does not require concomitant synthesis of movement protein during vascular transport. Mol. Plant-Microbe Interact. 8:784-787.

17. Gielen, J., Ultzen, T., Bontems, S., Loots, W., van Schepen, A., Westerbroek, A., de Haan, P., and van Grinsven, M. 1996. Coat proteinmediated protection to cucumber mosaic virus infections in cultivated 
tomato. Euphytica 88:139-149.

18. Golemboski, D. B., Lomonossoff, G. P., and Zaitlin, M. 1990. Plants transformed with tobacco mosaic nonstructural gene sequence are resistant to virus. Proc. Natl. Acad. Sci. U.S.A. 87:6311-6315.

19. Hayes, R. J., and Buck, K. W. 1990. Infectious cucumber mosaic virus RNA transcribed in vitro from clones obtained from cDNA amplified using the polymerase chain reaction. J. Gen. Virol. 71:2503-2508.

20. Hellwald, K. H., and Palukaitis, P. 1995. Viral RNA as a potential target for two independent mechanisms of replicase-mediated resistance against cucumber mosaic virus. Cell 83:937-946.

21. Kaplan, I. B., Shintaku, M. H., Li, Q., Zhang, L., Marsh, L. E., and Palukaitis, P. 1995. Complementation of virus movement in transgenic tobacco expressing the cucumber mosaic virus 3 a gene. Virology 209: 188-199.

22. Kariyama, T., Kuniyasu, K., and Mochizuki, H. 1971. Studies on the breeding of disease resistance in tomatoes by interspecific hybridization. II. Fertility and disease resistance in the progenies of interspecific hybridization. Bull. Hortic. Res. Stn. B (Okitsu) 11:33-60.

23. Koch, M., and Salomon, R. 1994. Serological detection of onion yellow dwarf virus in garlic. Plant Dis. 78:785-788.

24. Lomonossoff, G. P. 1995. Pathogen-derived resistance to plant viruses. Annu. Rev. Phytopathol. 33:323-343.

25. McCormick, S. 1991. Transformation of tomato with Agrobacterium tumefaciens. Plant Tissue Cult. Manual B 6:1-9.

26. Nguyen, L., Lucas, W. J., Ding, B., and Zaitlin, M. 1996. Viral RNA trafficking is inhibited in replicase-mediated resistant transgenic tobacco plants. Proc. Natl. Acad. Sci. U.S.A. 93:12643-12647.

27. Palukaitis, P., Roossinck, M. J., Dietzgen, R. G., and Francki, R. I. B. 1992. Cucumber mosaic virus. Adv. Virus Res. 41:281-348.

28. Palukaitis, P., and Zaitlin, M. 1997. Replicase-mediated resistance to plant virus disease. Adv. Virus Res. 48:349-377.

29. Phills, B. R., Provvidenti, R., and Robinson, R. W. 1977. Reaction of Solanum lycopersicoides to viral diseases of the tomato. Rep. Tomato Genet. Coop. 27:18.

30. Provvidenti, R., and Gonsalves, D. 1995. Inheritance of resistance to cucumber mosaic virus in transgenic tomato line expressing the coat protein gene of the white leaf strain. J. Hered. 86:85-88.

31. Reavy, B., Arif, M., Kashiwazaki, S., Webster, K. D., and Barker, H. 1995. Immunity to potato mop-top virus in Nicotiana benthamiana plants expressing the coat protein gene is effective against fungal inoculation of the virus. Mol. Plant-Microbe Interact. 8:286-291.

32. Rizzo, T. M., and Palukaitis, P. 1988. Nucleotide sequence and evolutionary relationships of cucumber mosaic virus (CMV) strains: CMV RNA 2. J. Gen. Virol. 69:1777-1787.

33. Roossinck, M. J., and Palukaitis, P. 1990. Rapid induction and severity of symptoms in zucchini squash (Cucurbita pepo) map to RNA 1 of cucumber mosaic virus. Mol. Plant-Microbe Interact. 3:188-192.

34. Saito, Y., Komari, T., Masuta, C., Hayashi, Y., Kumashiro, T., and Takanami, Y. 1992. Cucumber mosaic virus-tolerant transgenic tomato plants expressing a satellite RNA. Theor. Appl. Genet. 83:679-683.

35. Schiebel, W., Haas, B., Marinkovic, S., Klanner, A., and Sanger, H. L. 1993. RNA-directed RNA polymerase from tomato leaves. II. Catalytic in vitro properties. J. Biol. Chem. 268:11858-11867.

36. Suzuki, M., Kuwata, S., Kataoka, J., Masuta, C., Nitta, N., and Takanami, Y. 1991. Functional analysis of deletion mutants of cucumber mosaic virus RNA3 using an in vitro transcription system. Virology 183:106-113.

37. Taliansky, M. E., and Garcia-Arenal, F. 1995. Role of cucumovirus capsid protein in long-distance movement within the infected plant. J. Virol. 69:916-922.

38. Tomlinson, J. A. 1987. Epidemiology and control of virus diseases of vegetables. Ann. Appl. Biol. 110:661-681.

39. Traynor, P., Young, B. M., and Ahlquist, P. 1991. Deletion analysis of brome mosaic virus 2a protein: Effects on RNA replication and systemic spread. J. Virol. 65:2807-2815.

40. Wintermantel, W. M., Banerjee, N., Oliver, J. C., Paolillo, D. J., and Zaitlin, M. 1997. Cucumber mosaic virus is restricted from entering minor veins in transgenic tobacco exhibiting replicase-mediated resistance. Virology 231:248-257.

41. Xue, B., Gonsalves, C., Provvidenti, R., Slightom, J. L., Fuchs, M., and Gonsalves, D. 1994. Development of transgenic tomato expressing a high level of resistance to cucumber mosaic virus strains of subgroups I and II. Plant Dis. 78:1038-1041.

42. Zaitlin, M., Anderson, J. M., Perry, K. L., Zhang, L., and Palukaitis, P. 1994. Specificity of replicase-mediated resistance to cucumber mosaic virus. Virology 201:200-205.

43. Zitter, T. A. 1992. Cucumber mosaic virus. Pages 35-36 in: Compendium of Tomato Diseases. J. B. Jones, J. P. Jones, R. E. Stall, and T. A. Zitter, eds. The American Phytopathological Society, St. Paul, MN. 